STEPHANIE LETT

University of Carleton

\title{
The Arthur H. Tweedle Collection, Project Naming, and Hidden Stories of Colonialism
}

In the summer of 1945, the RMS Nascopie left harbour in Montreal, bound for the eastern Arctic. An icebreaker ship owned by the Hudson's Bay Company (HBC), the Nascopie had travelled to the North every summer since 1912 to deliver cargo to HBC outposts. This year, the passenger list included not only HBC employees, but also representatives from various departments of the Canadian government that had assumed responsibility for the health and welfare of Canada's Inuit peoples following the Second World War. It was under these auspices that optometrist Dr. Arthur H. Tweedle was sent to the North to examine the eyes of Inuit peoples on behalf of the Department of National Health and Welfare and the Canadian National Institute for the Blind. ${ }^{1}$

Tweedle, born near Hamilton, Ontario in 1900, was a well-respected optometrist and an accomplished amateur photographer. He was an active member of the Hamilton Camera Club who travelled widely throughout Canada taking photographs, and won a variety of prizes at camera club competitions across Ontario and Quebec. Tweedle travelled with two of the Nascopies summer voyages, in 1945 and 1946, capturing a variety of black and white photographs and colour slides along the way. ${ }^{2}$ He took photographs of the Inuit, their settlements, the Arctic landscape, and the activities of the ship and crew. These images were donated to Library and Archives Canada (LAC) by Tweedle's wife in 1976, shortly after his death, and have since been digitized through Project Naming, a photograph identification initiative created by LAC to allow Inuit families and communities to assist in the identification of unnamed individuals depicted in

\footnotetext{
${ }^{1}$ Peter Geller, Northern Exposures: Photographing and Filming the Canadian North, 1920-45 (Vancouver: University of British Columbia Press, 2004), 1 - 5; Arthur H. Tweedle Fonds, Library and Archives Canada, reference no. R848-0-4-E, http://collectionscanada.gc.ca/pam_archives/index.php?fuseaction=genitem.displayItem\&lang=eng \&rec nbr $=140850$.

${ }^{2}$ Arthur Tweedle Fonds
} 
archival photographs. ${ }^{3}$

When viewed in their new, digital context, accompanied by captions that were edited by Project Naming to include the names of those depicted, it is easy to assume that these photographs have been successfully "reclaimed" by Inuit communities and that they are ready to be used as a tool for educating the Canadian public about Inuit history. While Project Naming's impact in terms of acknowledging the agency and identities of Inuit depicted in the archival record cannot be underestimated, it is also important to consider the ways in which Tweedle's collection functions differently after being digitized, and to question the extent to which this new context leads to a reframing of the photographs' meaning. In fact, by removing the photographs from their original context as part of a wider collection of artefacts and textual records, the digitization of Tweedle's images has hidden much of the history and previous functions of these images from the public eye. While Project Naming strives to add Inuit voices to the narrative of Canadian history, the incomplete digitization of this collection has left many of their stories untold.

\section{Project Naming: “A Unique Collaboration”}

LAC launched Project Naming in 2002 in partnership with the Nunavut Sivuniksavut Training Program, an Ottawa-based post-secondary program for Inuit youth, and the Government of Nunavut's Department of Culture, Language, Elders and Youth. ${ }^{4}$ As a photographic identification project in which members of Inuit communities in Nunavut, the Northwest Territories, northern Quebec, and Labrador are asked to assist in the identification of unnamed Inuit in archival images, Project Naming serves as a direct response to the difficulties researchers face when attempting to find archival content related to Indigenous histories. LAC has acknowledged these challenges, noting that many of the original descriptions of these photographs use language that is problematic or vague, identifying Indigenous peoples through general descriptors like "Eskimo,"

\footnotetext{
${ }^{3}$ Ibid.

4. "Project Naming is Expanding!" Library and Archives Canada Blog, 29 May 2015, https://thediscoverblog.com/2015/05/28/project-naming-is-expanding/.
} 
"native," or "squaw" rather than with names. ${ }^{5}$ This type of language not only reflects the historical biases of non-Indigenous society, but also limits the capability of both Inuit and non-Inuit researchers to search for specific individuals, families, or communities within the archival record.

Since 2002, approximately 8000 images of Inuit subjects have been digitized through the project and are accessible on LAC's website, including most of the photographs from Tweedle's trips on the Nascopie. The photographs are shared with northern Inuit communities through social media, community slide shows, local newspapers, and on-site research visits. ${ }^{6}$ Oral histories and information about the photographs are gathered, including the names of subjects, places, and activities depicted in the images, and, whenever possible, captions are edited in the online collection to indicate these histories. ${ }^{7}$

According to Beth Greenhorn, project manager at LAC and leader of the Project Naming team, Project Naming aims to make LAC's collections more accessible to all Canadians, including Inuit peoples living in remote communities. It strives to prompt discussions about the past between Inuit youth and Elders, and to preserve what is left of the living memory of the subjects and places depicted in the photographs. Finally, it endeavours to improve all Canadians' understanding of Inuit histories and to give agency to the Indigenous peoples of northern Canada in telling their own stories. ${ }^{8}$

LAC and the Government of Canada have celebrated Project Naming's successful implementation of best practices of sharidng authority within an archival setting. Beth Greenhorn has stated, for example, that Project Naming "benefits Inuit, the archival community, and all Canadians. It is an excellent example of how the archival community can collaborate with and benefit by the

\footnotetext{
5 "Naming Aboriginal Canadians," Library and Archives Canada Blog, last modified 21 June 2016, https://thediscoverblog.com/2016/06/21/naming-aboriginal-canadians/.

6 "Project Naming: The first ten years and beyond," Library and Archives Canada Blog, 9 May 2013, https://thediscoverblog.com/2013/05/09/project-naming-the-first-ten-years-and-beyond/.

7 “The Naming Continues: Project Naming Photograph Information Form," Library and Archives Canada, last modified 29 January 2009, https://www.collectionscanada.gc.ca/inuit/020018-1401e.html.

${ }^{8}$ Beth Greenhorn, "Project Naming: Always On Our Minds," in Museums and the Web 2005: Proceedings, eds. J. Trant and D. Bearman (Toronto: Archives \& Museum Informatics, 2005), http://www.archimuse.com/mw2005/papers/greenhorn/greenhorn.html.
} 
input of a cultural community." "Similarly, Librarian and Archivist of Canada Dr.

Guy Berthiaume has praised the project for its collaborative nature: "Project Naming relies on a unique collaboration between the public and a memory institution like ours. Not only does the public's contribution enrich our photo collection at LAC, but past experience shows that such initiatives will trigger a dialogue between older and younger Aboriginal generations and help them to connect with their past." 10

\section{Reclaiming Identities}

Project Naming has been successful in its attempt to reclaim identities not previously acknowledged in LAC's archival record. Almost 2000 Inuit individuals, activities, and place names have been identified since the start of the project. ${ }^{11}$ This is a significant achievement, given the history of colonial naming practices in the Canadian North, and the importance of names to Inuit culture and identity. Names of people and places were often used as a tool of imperialism in Canada's colonial past. Place names such as Frobisher Bay, Cornwallis Island, and Baffin Island reflect the British colonisation of northern Canada. ${ }^{12}$ The arrival of Anglican and Catholic missionaries in the Arctic in the late nineteenth century also directly impacted Inuit identities, as missionaries began to assign biblically-inspired names to the Inuit in order to undermine their traditional beliefs. ${ }^{13}$ In the years following the Second World War, when Arthur H. Tweedle embarked on his voyages, the Canadian government altered Inuit naming practices once again, assigning an identification number to each Inuk that would be used to administer health, welfare, and education programs. The numbers, which southern Canadians found easier to pronounce and keep track of than traditional Inuit names, were stamped onto leather disks that Inuit had to wear around their necks at all times. ${ }^{14}$

\footnotetext{
${ }^{9}$ Ibid.

10 "News Release: Library and Archives Canada launches national Aboriginal photo identification project," Government of Canada, last modified 28 May 2015,

https://www.canada.ca/en/news/archive/2015/05/library-archives-canada-launches-nationalaboriginal-photo-identification-project.html.

11 “Project Naming," Library and Archives Canada, last modified 6 September 2016, http://www.baclac.gc.ca/eng/discover/aboriginal-heritage/project-naming/Pages/introduction.aspx.

${ }^{12}$ Carol Payne. "Lessons with Leah: re-reading the photographic archive of nation in the National Film Board of Canada's Still Photography Division.” Visual studies 21, no. 1 (2006): 17.

${ }^{13}$ Greenhorn.

14. Ibid.
} 
More broadly, scholars Alison K. Brown and Laura Lynn Peers have explained the separation of Indigenous peoples from their identities and histories in the captions of historic and contemporary photographic archives, which often describe Indigenous subjects using generalities while white subjects are given a full name and title. ${ }^{15}$ Carol Payne and Jeffrey Thomas have argued that photographic archives are sites of imperialism and "Aboriginal subjugation," where Indigenous peoples must face "the realities of historic colonialism and neo-colonialism." 16

These colonizing efforts are particularly deplorable given that "names are the heart and soul of Inuit culture." 17 The Inuit believe that names are essential to a person's identity, embodying their personality, values, and skills. If an Inuk's name is changed through ritual, or through colonization, the Inuk becomes a different person. ${ }^{18}$ Names hold spiritual significance as well; Inuit often celebrate individuals and communities by choosing to name their children after relatives who have died. These relatives are seen as protectors of their namesakes throughout many generations. ${ }^{19}$

Within the Arthur H. Tweedle fonds, there are many examples of photographs where the original captions leave Inuit subjects nameless. Figure 1, for instance, is captioned with the vague phrase "Inuit girl holding a pup." White, southern Canadians, such as the dentist depicted in a photo captioned "Dr. Hemmerick, dentist, examining an Inuit mother, her child is in her hood," are almost always named (Figure 2). Moreover, Inuit subjects are sometimes named with reference to white individuals who are not depicted in the photographs themselves, including the woman in Figure 3, who is described as "Inuit woman, who is Mrs. Bert Swaffield's maid.”

\footnotetext{
15 Alison K. Brown and Laura Lynn Peers, Pictures bring us messages: Sinaakssiiksi aohtsimaahpihkookiyaawa: Photographs and Histories from the Kainai Nation (Toronto: University of Toronto Press, 2006), $110-111$.

${ }^{16}$ Carol Payne and Jeffrey Thomas, "Aboriginal Interventions into the Photographic Archives," Visual Resources: An International Journal of Documentation, XVIII, no. 2 (June 2002): 110.

${ }_{17}$ Valerie Alia. Names and Nunavut: Culture and Identity in the Inuit Homeland (New York: Berghahn Books, 2009), 17.

18 Ibid., 20.

19 Ibid.
} 


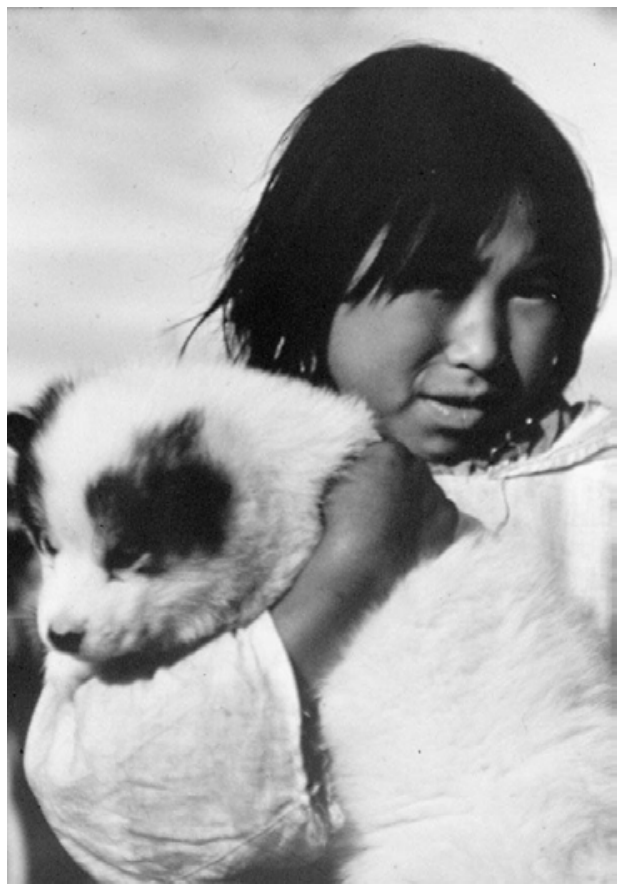

Figure 1: Inuit girl holding a pup, ca. 1946

(Source: Library and Archives Canada/Arthur H. Tweedle fonds/a184695)

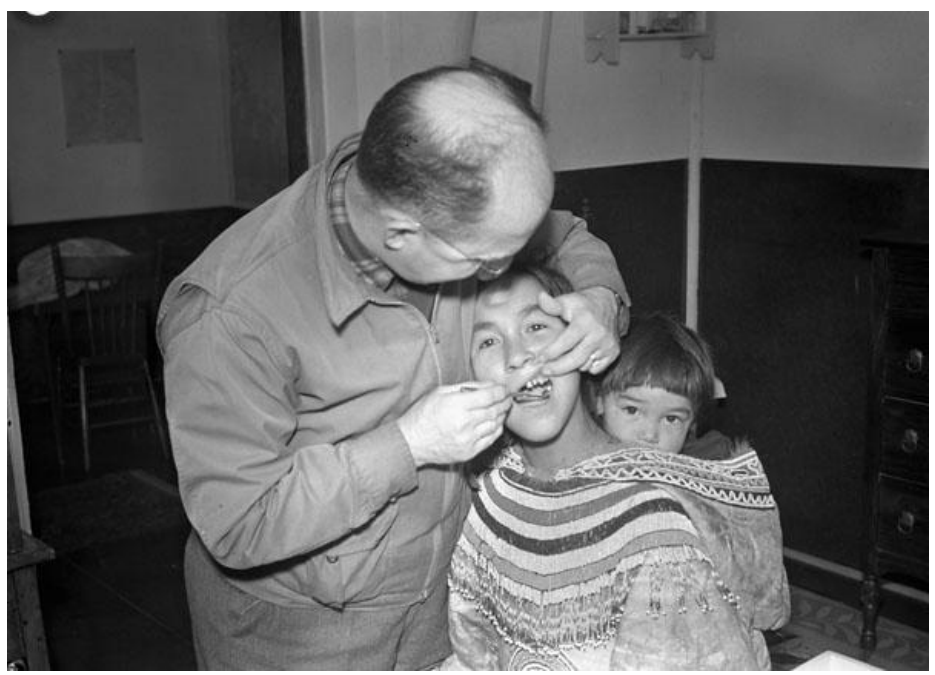

Figure 2: Dr. Hemmerick, dentist, examining an Inuit mother, her child is in her hood, September 12, 1945

(Source: Library and Archives Canada/Arthur H. Tweedle fonds/a 184847) 
Photographs with captions that have been edited through Project Naming contrast sharply with those in which Inuit have been denied their own identity. They represent the reclamation of images and identities by their subjects and the wider Inuit community. One of Tweedle's photographs, originally captioned "Inuit woman and children at Pond Inlet," has been updated with the following inscription: "Letia Kyak with her daughter Leah (standing) and son Moses (in the amauti)" (Figure 4). Likewise, the record of a photograph originally identified as "Inuit family standing outside at Pond Inlet" has been updated to include the names of its subjects: "Ipeelie (Ipilee) Merkosak and his wife Leah Sigluk Merkosak with their son Akittiq on the left, and daughter Martha (Mata) in the middle” (Figure 5).

Editing the original captions of Tweedle's photographs to recognize the identities of Inuit subjects recognizes the importance Inuit names to their individual and cultural identities, and allows Inuit peoples to reclaim a place in a field in which they have been historically marginalized. Participants in Project Naming have described the meaningful and affecting nature of their work. Matthewsie Ashevak, who interviewed Inuit Elders about photographs from another collection that was digitized through the project, explained that "it was so exciting showing these Elders the pictures...when I clicked onto each picture, I watched their eyes. As they recognized an individual, they would have a big smile on their faces, and acted as if these pictures were taken just yesterday.” 20

On a practical level, these textual changes are particularly meaningful because of the photographs' digital format. As historian James Opp has argued, textual data has taken on a new importance with the digitization of photographic archives and the fact that their accompanying texts are now fully searchable. ${ }^{21}$ This means that items digitized and edited through Project Naming can now be found by searching for the names of particular individuals or communities.

Significantly, Library and Archives Canada has chosen not to completely replace original captions with those edited by Project Naming. Rather, the original

\footnotetext{
${ }^{20}$ David A. Smith, "From Nunavut to Micronesia: Feedback and Description, Visual Repatriation and Online Photographs of Indigenous Peoples," The Canadian Journal of Library and Information Practice and Research 3, no. 1 (2008): 7.

${ }^{21}$ James Opp, “The Colonial Legacies of the Digital Archive: The Arnold Lupson Collection,”

Archivaria 65 (Spring 2008): 7.
} 
inscription is retained, with names collected through the project separated by square brackets. An explanation of this practice is included on the item-level web page for each digitized photograph. This maintenance of the integrity of the original captions is important if the history and context of the archival record is to be maintained. As Brown and Peers have argued, the language used to caption photos at the time they were collected must be distinct from that which has been altered by archival institutions in the present. ${ }^{22}$ Historian and archivist Joan M. Schwartz has also emphasized the importance of "noting when, by whom, and why changes in the descriptive record or standard terms are made, for those changes...embody not only changing social or cultural or political circumstances, but also the history of our own archival practices. ${ }^{23}$ In collaborating with Inuit communities to restore the identities of the subjects of these photos, and by maintaining a historical record of the changes that have been made as a result of this process, Project Naming has become a valuable tool for sharing authority within the archives and for expanding Canadians' knowledge of Indigenous history in the North.

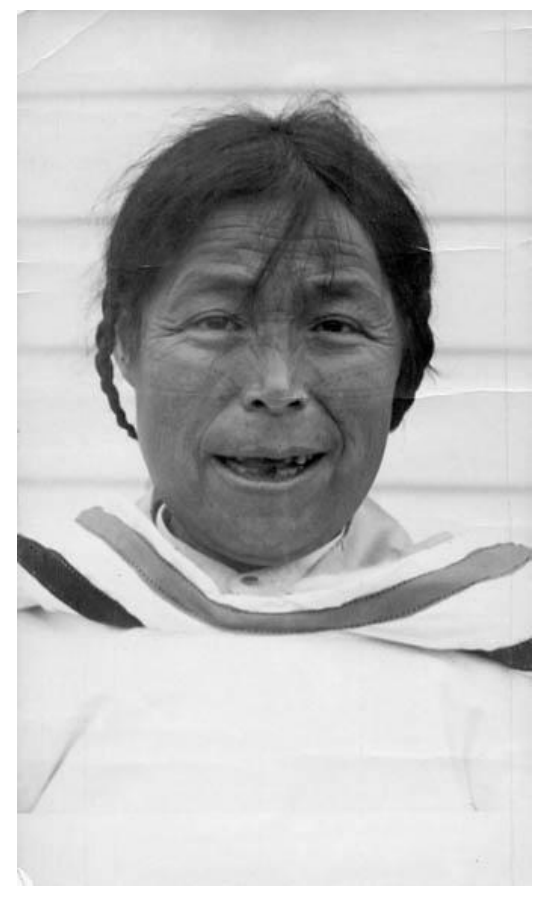

Figure 3: Inuit woman, who is Mrs. Bert Swaffield's maid, 30 - 31 August 1945 (Source: Library and Archives Canada/Arthur H. Tweedle fonds/e002344263)

\footnotetext{
22 Brown and Peers, 178.

${ }^{23}$ Joan M. Schwartz, "Coming to Terms with Photographs," Archivaria 54 (2002): 159.
} 
Figure 4: Inuit woman and children at Pond Inlet [Letia Kyak with her daughter Leah (standing) and son Moses (in the amauti)], August, 1945

(Source: Library and Archives Canada/Arthur H. Tweedle fonds/a186216)
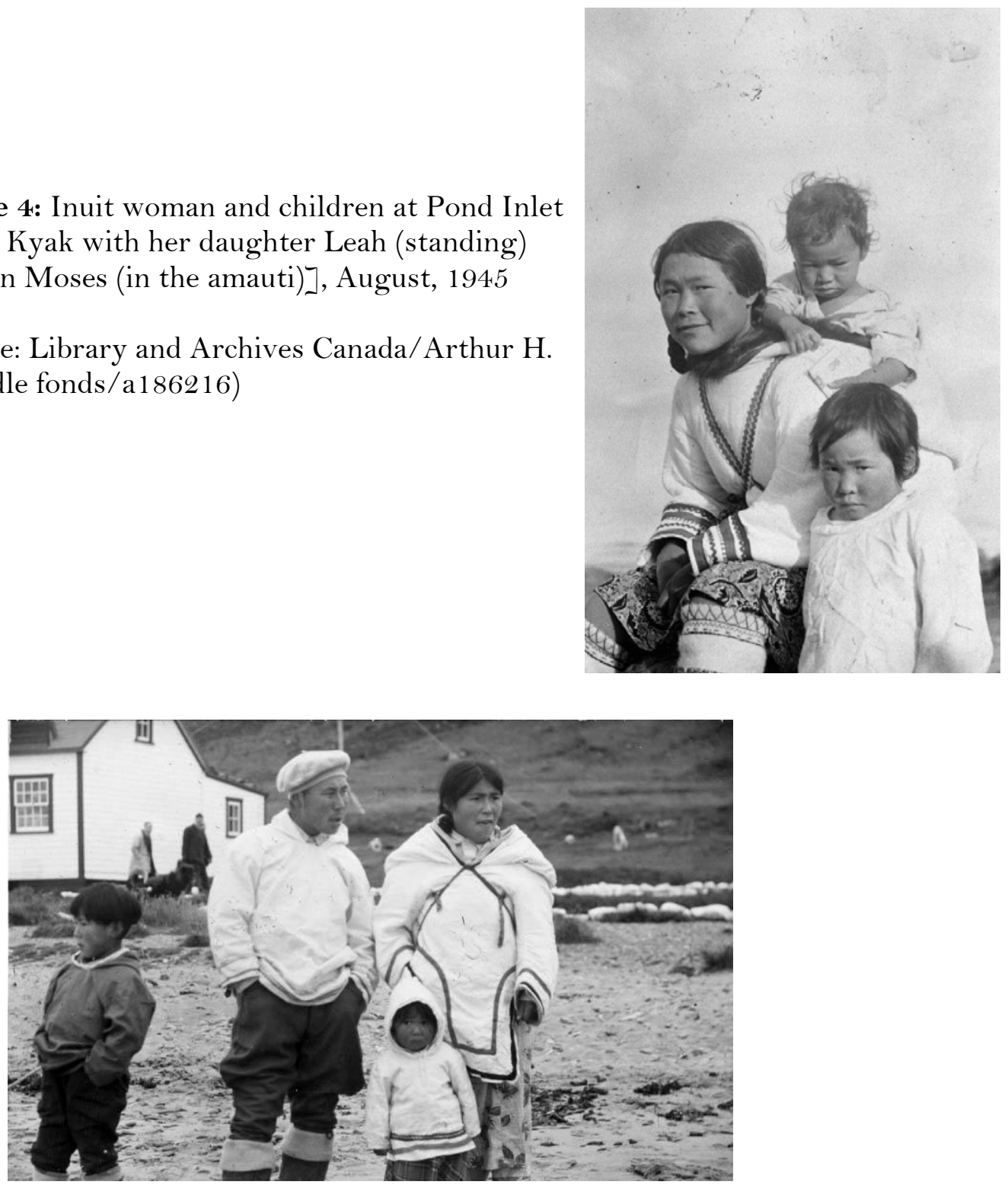

Figure 5: Inuit family [Ipeelie (Ipilee) Merkosak and his wife Leah Sigluk Merkosak with their son Akittiq on the left, and daughter Martha (Mata) in the middle] standing outside at Pond Inlet (Mittimatalik/Tununiq), Nunavut, August 1945

(Source: Library and Archives Canada/Arthur H. Tweedle fonds/e002344275) 


\section{Hidden Stories}

It is clear that Project Naming has made important contributions to the accuracy of LAC's photographic collections, including the Arthur H. Tweedle collection, and to the restoration of Inuit history, identity, and agency within these records. However, it is also important to acknowledge the effect that digitization has had on the meaning of Tweedle's photographs. While LAC has been careful to preserve the original text that accompanies each photograph, digitization of these images has removed them from a context that reveals their histories and past functions. The Tweedle collection is made up largely of photographs, but also includes textual records that have not been digitized. As a consequence, the digital collection has been left to tell an incomplete story of Canada's colonial past and its impact on the peoples of Nunavut.

The archivists digitizing photographs through Project Naming aimed to do so in a way that "helped preserve the original collections." ${ }^{24}$ Research suggests, however, that the very nature of digitization prevents complete preservation of the archival record. James Opp argues that the digitization of a photograph removes it from its wider and originally intended context, resulting in a loss of materiality and a narrowed definition of the image as a historical object. He points specifically to the importance of text, noting that publication of photographs online without their accompanying text removes them from "the context of their own production." 25 Similarly, Joanna Sassoon describes digitization as a process of subjectivity and exclusion. Rather than remaining objective, institutions like LAC leave their mark on a collection as they decide which materials should be digitized, and which should not. ${ }^{26}$ She writes that tools for online access, with limited searching capabilities and textual information, hide past contexts and functions of photographs and leave them "relegated to content-based digital orphans." 27 Allan Sekula has written that this loss of context can be seen in all archival practices, which "liberate" photographs from their functions outside of the archive. Photographs do not reveal

\footnotetext{
${ }^{24}$ Smith, $7-8$.

25 Opp, 12.

${ }^{26}$ Joanna Sassoon, "Photographic Materiality in the Age of Digital Reproduction," in Photographs

Objects Histories: On the Materiality of Images, eds. Elizabeth Edwards and Janice Hart, $186-202$

(London and New York: Routledge, 2004), 195.

27 Sassoon, 192.
} 
the objective truth, but instead draw meaning from how and where they are presented. ${ }^{28}$

The presentation of Arthur H. Tweedle's collection online has, for example, hidden the past lives and uses of his photographs. While one might read the images on the LAC website as simply a visual record collected by a tourist, meant for compilation in a personal or family album, the undigitized textual records in Tweedle's files suggest that they were used as part of a wider effort to depict Inuit peoples as "others" in Canada. They were part of what Peter Geller describes as a "project of producing the North as an object of knowledge and understanding" for southern Canadians. ${ }^{29}$ This is particularly evident in several newspaper clippings that Tweedle saved, in which his photographs were used to communicate a paternalistic, colonial message regarding the subjects of his photographs and the Inuit peoples of northern Canada. On October 2, 1946, for example, the Toronto Daily Star published a number of Tweedle's photographs, featuring them prominently on the first page of their second section (Figure 6). One of the portraits, of an Inuit man wearing a fur hat, has also been digitized by LAC, with the original caption reading "Joannesse, an Inuit man, Cape Smith, N.W.T. [Nunavut], 1945 - 1946" (Figure 7). In contrast, the newspaper described the photograph with a caption that suggests the inferiority and backwardness of the Inuit peoples: "At Dorset, the home of this husky native, Eskimos have gone modern, living in tents purchased from the trading post there, during the summer months when days are long." This text implies that the Inuit require the influence of trading posts set up by white, southern Canadians in order to hold a place in the modern world. Like many of the photographs taken in the North at this time, they celebrate what scholar Carol Payne refers to as "benevolent southern interventions." ${ }^{30}$ Tweedle's photographs are being used here as part of an effort to create an imagined community among southern Canadians by depicting the people of the north as "others" who benefit from the civilizing efforts of the Canadian

${ }^{28}$ Allan Sekula, Mining Photographs and Other Pictures, 1948 - 1968 (Halifax: Press of the Nova Scotia College of Art and Design and the University College of Cape Breton Press, 1983), 444-445.

${ }^{29}$ Geller, 5.

30 Payne, 11. 
government. ${ }^{31}$

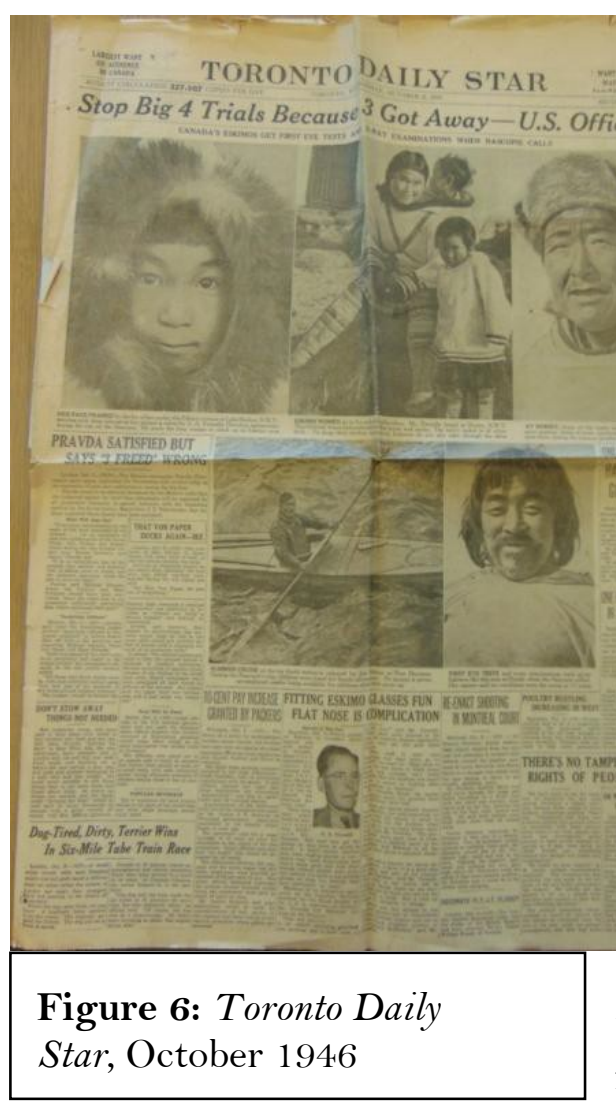

This paternalistic, patronizing discourse appeared once again when more of Tweedle's photographs were published in The Globe and Mail on February 2, 1946. ${ }^{32}$ Two prominently featured photographs show southern Canadians sponsored by the Canadian government, including Tweedle himself, examining and treating the eyes of Inuit individuals. The caption reads, "When the Hudson's Bay Company supply ship Nascopie went into the far north last year, the Government, cooperating with the Canadian National Institute for the Blind, which supplied the technicians, arranged for eye examinations and glasses fittings for the

Eskimos. At left, A.H. Tweedle...examines the eyes of an Eskimo woman while her son looks on in wonder." This emphasis on government benevolence is reinforced by the composition of the photo itself, in which Tweedle takes on a paternal and dominant position in the foreground while the Inuit woman and child appear to shrink back and gaze up at Tweedle "in wonder."

A portrait of a young girl wearing glasses fitted by Tweedle is also featured on this page of The Globe, and within its caption another theme emerges that is common to several of the textual records in Tweedle's files: the othering of the Inuit's physical features. The original caption noted in LAC's digital archive reads "portrait of an Inuit child being fitted for glasses," and without further context, viewers may see this as further evidence of the benevolence of Tweedle and the Canadian government (Figure 9). In fact, the newspaper's caption makes clear that

\footnotetext{
${ }^{31}$ Ibid., 4

32 "Eye Specialists Aid Eskimos During Nascopie Trip into Arctic.” The Globe and Mail, p. 15, 2 February 1946. File 1. Arthur H. Tweedle fonds. Reference no. R848-0-4-E. Library and Archives Canada.
} 
this image was used to emphasize a natural and physical divide between white, southern Canadians and the Inuit: "The flat bridge on this youngster's nose meant that A.H. Tweedle had to practically remake the glasses so she could wear them. He had the same difficulty with glasses for all pure Eskimos." 33 The reference to "pure Eskimos" also exemplifies the ideology of the "vanishing race," which was based on both the notion that Indigenous "races" were physically different from a superior white "race," and the idea that traditional Indigenous peoples were disappearing because of their inability to adapt to the changes brought by modernity. Photographs were thought of as a valuable tool for creating simulacra of Indigenous peoples and cultures and, as explained by well-known early twentieth century American photographer Edward S. Curtis in his twenty-volume photographic project The North American Indian, to create a historical record of a race that was "passing into the darkness of an unknown future." ${ }^{44}$

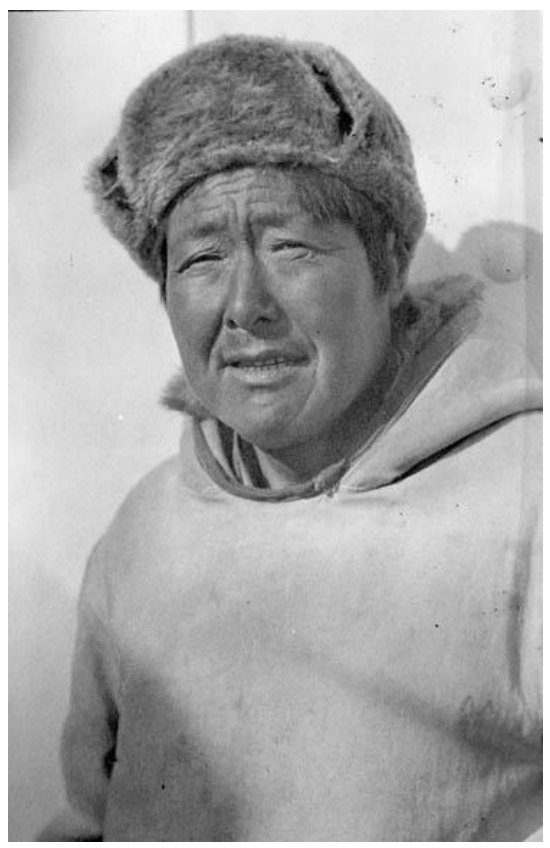

Figure 7: Joannesse, an Inuit man, Cape Smith, N.W.T. [Nunavut], 1945-1946

(Source: Library and Archives Canada/Arthur H. Tweedle fonds/e002344219)

33 Ibid.

${ }^{34}$ Martha A. Sandweiss, Print the Legend: Photography and the American West (New Haven and London: Yale University Press, 2002), 217 - 219; Brian W. Dippie, "Photographic Allegories and Indian Destiny," in Readings in Aboriginal Studies volume 4, Images of the Indian, ed. Joe Sawchuck (Brandon: Bearpaw Publishing, 1995), 50. 


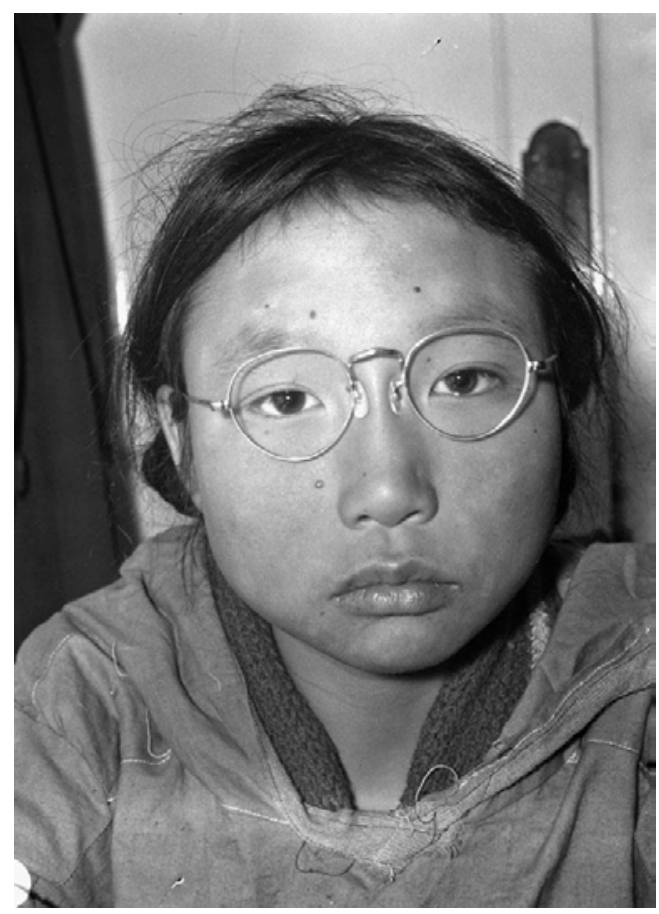

Figure 9: Portrait of an Inuit child being fitted for glasses, 9 Sept. 1945

(Source: Library and Archives

Canada/Arthur H. Tweedle fonds/a184856)

The notion of physical difference was referenced again in an article published by The Etobicoke Press in November 1946, which also blamed Tweedle's difficulty with providing properly fitting glasses to the Inuit on their physical difference from non-Indigenous Canadians: "To fit glasses to the flat Mongolian faces of the Eskimos was a problem complicated by a lack of noses to support the frames." ${ }^{35}$ An article written by Tweedle for the November 1947 issue of the Canadian Journal of Optometry echoes this sentiment, drawing a direct comparison between Inuit and white Canadians: "The extremely broad heads required the temples to be either bowed out, or the frame to be fitted with extra long endpieces...It was observed that in many fittings the ears were relatively much higher than the eyes as compared with whites." 36 Without the opportunity to consult these textual documents, viewers of Tweedle's digitized collection will be left unaware of his photographs' roles as tools for the physical othering of Canada's Inuit peoples.

\footnotetext{
35 "Know Your Neighbour: Optometrist has a Keen Eye for Pictures, Too: Etobicoke Man has Record of His Arctic Jaunts, The Etobicoke Press, p. 4, 7 November 1946, File 1, Arthur H. Tweedle fonds, Reference no. R848-0- 4-E, Library and Archives Canada.

${ }_{36}$ Tweedle, A.H., "Visual Survey of East Canadian Arctic Eskimos," The Optical Journal and Review of Optometry LXXXIV, no. 21, 1 November 1947, File 8, Arthur H. Tweedle fonds, Reference no. R848o-4-E, Library and Archives Canada, $37-38$.
} 
Also absent from the digital record of Tweedle's collection is an emphasis on specific gender roles for Inuit men and women that is present in many of the texts held in his files at LAC. Photography of the Canadian North at this time often projected southern ideas of gender onto the Inuit peoples, romanticizing images of Inuit women as mothers and nurturers, and of men as hunters and providers. ${ }^{37}$ This notion is evident in Tweedle's journal article, which suggests that "the Eskimo, being a hunter, is dependent on good distant vision for his livelihood. The Eskimo woman must be able to see well at near in order to sew for the family." 38 Tweedle's files also include the text of a radio advertising programme sponsored by Purity Flour Mills Limited, which not only outlines the importance of glasses for Inuit women who "ruin their eyes" by sewing clothes and tents, but also includes a story about an Inuit woman considered to be "the most beauteous wench in the North," for whom the white authorities aboard the Nascopie were attempting to find a husband. ${ }^{39}$ Tweedle's conception of Inuit women as domestic and nurturing, and of Inuit men as strong hunters, is present in his photographs that were digitized as part of Project Naming. Nearly every photo in which an Inuit woman is a subject depicts women with children, often in the woman's parka hood (see figures 2 and 4, for example). Inuit men are almost never depicted with children or families. Instead, images of Inuit men often show them on the ship or doing physical labour, such as unloading cargo (Figure 10). However, the photographs' function as a means of projecting gender roles onto the Inuit is less explicit in these images than in Tweedle's textual files. If they are viewed without this context, they may be misinterpreted as truthful depictions of the lives of men and women in the North.

\footnotetext{
${ }^{37}$ Geller, 170.

38 Tweedle, A.H., "Visual Survey of East Canadian Arctic Eskimos," 39

${ }^{39}$ McKim Advertising Limited, "This Is Canada: Floating Friend” [radio programme], Toronto, File

7, Arthur H. Tweedle fonds, Reference no. R848-0-4-E, Library and Archives Canada.
} 


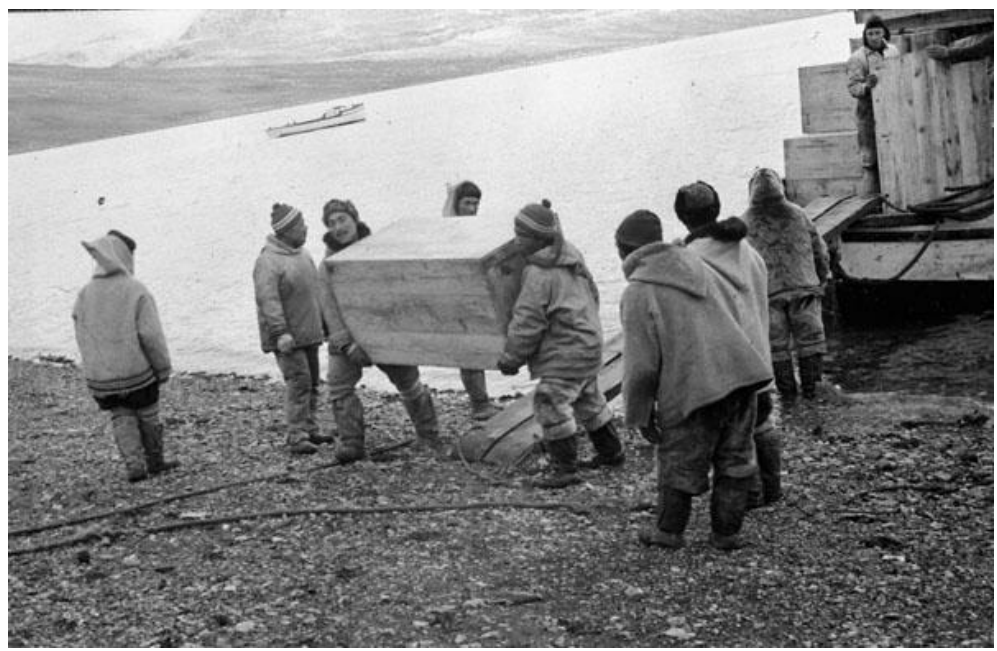

Figure 10: Unloading at Pond Inlet: Inuit men remove cargo from the supply boat, 7 Sept. 1945

(Source: Library and Archives Canada/Arthur H. Tweedle fonds/a186223)

Viewing Tweedle's photographs in the context of their production and circulation, rather than in their isolated digital format, makes the colonial, othering nature of the images much more clear. These were not simply photographs taken by a curious amateur photographer, for display in a personal album or at a small camera club gathering. Rather, they were widely circulated in prominent Canadian newspapers and, as some of the newspaper articles note, displayed at several community events hosted by Tweedle. ${ }^{40}$ The paternalism and prejudice that they were used to support was referenced by Tweedle and his colleagues in medical journals and radio programmes. While LAC has been careful to maintain a historical record in the captions of the photographs, failing to include these textual documents in the digital archive of Tweedle's collection has left them to be what Sassoon calls "digital orphans." 41 The circumstances of their production and circulation have been hidden, giving viewers an incomplete understanding of their historical function.

40 "Know Your Neighbour," The Etobicoke Press.

${ }^{41}$ Sassoon, 192. 


\section{Conclusion}

Digitization of textual records, and increasing their connectedness to their visual counterparts, may be a process that demands a great deal of time and monetary resources. However, as public historians work with this twenty-first century medium, they have a responsibility to tell complete stories. In many ways, Project Naming has been a great success. An outstanding number of photographs have been digitized through this initiative and, in many of them, culturally significant names of people and places have been revealed as Inuit Elders and communities work to reclaim their history. However, as this investigation of the Arthur H. Tweedle collection has demonstrated, Library and Archives Canada's work is not yet finished. The incomplete digitization of Tweedle's files has left his photographs to exist as "digital orphans," alienated from their past lives and functions and available to be reframed in countless ways in the online world. They now exist on a platform that allows for Inuit peoples to reclaim identities not previously acknowledged in the archival record, but, by hiding much of the history of the photographs themselves, the digitization of the Tweedle collection risks telling an incomplete story in a different way. 


\section{Bibliography}

\section{Archival Sources}

Arthur H. Tweedle Fonds, "Dr. Hemmerick, dentist, examining an Inuit mother, her child is in her hood," 12 September 1945, Clyde River (Nunavut), photographed by Arthur H. Tweedle, Library and Archives Canada, accession no. 1978-162 NPC, reproduction no. PA-184847, http://collectionscanada.gc.ca/pam_archives/index.php?fuseaction=geni tem.displayItem\&lang $=$ eng\&rec_nbr $=3512395$.

. "Inuit child and dog," 1945, Fort Ross (Nunavut), photograph by Arthur H. Tweedle, accession no. 1978 - 162 NPC, reproduction no. PA-18475, http://collectionscanada.gc.ca/pam archives/index.php?fuseaction=geni tem.displayItem\&lang $=$ eng\&rec_nbr $=3511645$.

"Inuit family [Ipeelie (Ipilee) Merkosak and his wife Leah Sigluk Merkosak with their son Akittiq on the left, and daughter Martha (Mata) in the middle] standing outside at Pond Inlet (Mittimatalik/Tununiq), Nunavut, August 1945." 30 - 31 August 1945, Nunavut, photograph by Arthur H. Tweedle, Library and Archives Canada, accession no. 1978-162 NPC, reproduction copy number e002344275, http://collectionscanada.gc.ca/pam_archives/index.php?fuseaction=geni tem.displayItem\&lang $=$ eng\&rec_nbr $=3606620$.

"Inuit girl beside dock. [Maryann Tattuinee. This photograph was probably taken at Coral Harbour, Southampton Island. Ms. Tattuinee now lives in Rankin Inlet.] ca. 1945-1946," ca. 1945 - 1946, unknown location, photograph by Arthur H. Tweedle, accession no. 1978-162 NPC, reproduction no. e002344234, http://collectionscanada.gc.ca/pam archives/index.php?fuseaction=geni tem.displayItem\&lang $=$ eng\&rec_nbr $=3198759$.

"Inuit girl holding a pup," ca. 1946, unknown location, photographed by Arthur H. Tweedle, Library and Archives Canada, accession no. 1978-162 NPC, reproduction no. PA-184695, http://collectionscanada.gc.ca/pam archives/index.php?fuseaction=geni tem.displayItem\&lang $=$ eng $\&$ rec $n b r=3511502$.

---, "Inuit woman and children at Pond Inlet [Letia Kyak with her daughter Leah (standing) and son Moses (in the amauti)].” August 1945, Pond Inlet, photograph by Arthur H. Tweedle, Library and Archives Canada, accession no. 1978-162 NPC, reproduction copy no. PA- 186216 , http://collectionscanada.gc.ca/pam_archives/index.php?fuseaction=geni tem.displayItem\&lang=eng\&rec nbr=3512494.

"Inuit woman, who is Mrs. Bert Swaffield's maid," $30-31$ August 1945, Pond Inlet (Nunavut), photograph by Arthur H. Tweedle, Library and Archives Canada, accession no. 1978-162 NPC, reproduction no.

E002344263, http://collectionscanada.gc.ca/pam_archives/index.php?fuseaction=geni tem.displayItem\&lang $=$ eng\&rec nbr $=3606611$.

. "Joannesse, an Inuit man, Cape Smith, N.W.T. [Nunavut], 1945-1946," ca. 1945, Cape Smith (Nunavut), photograph by Arthur H. Tweedle, 
Library and Archives Canada, accession no. 1978-162 NPC, reproduction copy no. E002344219,

http://collectionscanada.gc.ca/pam_archives/index.php?fuseaction=geni tem.displayItem\&lang $=$ eng\&rec $n b r=3198758$.

. "Portrait of an Inuit child being fitted for glasses," 5 September 1945, Arctic Bay (Nunavut), photograph by Arthur H. Tweedle, Library and Archives Canada, accession no. 1978 - 162 NPC, reproduction copy no. PA-184856, http://collectionscanada.gc.ca/pam_archives/index.php?fuseaction=geni tem.displayItem\&lang $=$ eng\&rec $n b r=3512385$.

. "Unloading at Pond Inlet: Inuit men remove cargo from the supply boat," 7 September 1945, Pond Inlet (Nunavut), photograph by Arthur H.

Tweedle, Library and Archives Canada, accession no. 1978-162 NPC, reproduction copy no. PA-186223,

http://collectionscanada.gc.ca/pam_archives/index.php?fuseaction=geni tem.displayItem\&lang $=$ eng\&rec nbr $=3512500$.

“Arthur H. Tweedle Fonds.” Library and Archives Canada. Reference no. R848O-4-E.

http://collectionscanada.gc.ca/pam archives/index.php?fuseaction=geni tem.displayItem\&lang $=$ eng\&rec $\_n b r=140850$.

"Eye Specialists Aid Eskimos During Nascopie Trip into Arctic." The Globe and Mail, p. 15, 2 February 1946. File 1. Arthur H. Tweedle fonds. Reference no. R848-0-4-E. Library and Archives Canada.

"Fitting Eskimo Glasses Fun, Flat Nose is Complication." Toronto Daily Star, section 2, p. 1, 2 October 1946. File 1. Arthur H. Tweedle fonds.

Reference no. R848-0-4-E. Library and Archives Canada.

"Know Your Neighbour: Optometrist has a Keen Eye for Pictures, Too: Etobicoke Man has Record of His Arctic Jaunts.” The Etobicoke Press, p. 4, 7 November 1946. File 1. Arthur H. Tweedle fonds. Reference no. R848o-4-E. Library and Archives Canada.

McKim Advertising Limited. "This Is Canada: Floating Friend" [radio programme]. Toronto. File 7. Arthur H. Tweedle fonds. Reference no. R848-0-4-E. Library and Archives Canada.

Tweedle, A.H. "Visual Survey of East Canadian Arctic Eskimos." The Optical Journal and Review of Optometry LXXXIV, no. 21: 34 - 39. 1 November 1947. File 8. Arthur H. Tweedle fonds. Reference no. R848-0-4-E. Library and Archives Canada. 


\section{Web Sources}

"Naming Aboriginal Canadians." Library and Archives Canada Blog. Last modified June 21, 2016.

https://thediscoverblog.com/2016/06/21/naming-aboriginalcanadians/.

"News Release: Library and Archives Canada launches national Aboriginal photo identification project." Government of Canada. Last modified May 28, 2015. http://news.gc.ca/web/articleen.do? $\mathrm{mthd}=$ tp $\&$ crtr.page $=1 \&$ nid $=981009 \& \mathrm{crtr} . \operatorname{tp} 1 \mathrm{D}=1$.

"Project Naming." Library and Archives Canada. Last modified September 6, 2016. http://www.bac-lac.gc.ca/eng/discover/aboriginalheritage/project- naming/Pages/introduction.aspx.

"Project Naming: The first ten years and beyond." Library and Archives Canada Blog. May 9, 2013. https:// thediscoverblog.com/2013/05/09/projectnaming-the-first-ten-years-and- beyond/.

“Project Naming is Expanding!" Library and Archives Canada Blog. May 29, 2015. https://thediscoverblog.com/2015/05/28/project-naming-isexpanding/.

"The Naming Continues: Project Naming Photograph Information Form" Library and Archives Canada. Last modified January 29, 2009. https://www.collectionscanada.gc.ca/inuit/020018-1401-e.html.

Books and Articles

Alia, Valerie. Names and Nunavut: Culture and Identity in the Inuit Homeland. New York: Berghahn Books, 2009.

Brown, Alison K., and Laura Lynn Peers. Pictures Bring Us Messages: Sinaakssiiksi aohtsimaahpihkookiyaawa: Photographs and Histories from the Kainai Nation. Toronto: University of Toronto Press, 2006.

Brown, Deidre. "Protecting indigenous cultural property in the age of digital democracy: Institutional and communal responses to Canadian First Nations and Māori heritage concerns." Journal of Material Culture 17, no. 3 (2012): 307-324.

Dippie, Brian W. "Photographic Allegories and Indian Destiny." In Readings in Aboriginal Studies volume 4, Images of the Indian, ed. Joe Sawchuck, 48-81. Brandon: Bearpaw Publishing, 1995.

Geller, Peter Northern Exposures: Photographing and Filming the Canadian North, 1920-45. Vancouver: University of British Columbia Press, 2004.

Greenhorn, B., "Project Naming: Always On Our Minds." In Museums and the Web 2005: Proceedings, eds. J. Trant and D. Bearman. Toronto: Archives \& Museum Informatics, 2005.

http://www.archimuse.com/mw2005/papers/greenhorn/greenhorn.htm $\underline{1 .}$

Opp, James. "The Colonial Legacies of the Digital Archive: The Arnold Lupson Collection." Archivaria 65 (Spring 2008): 3-19.

Ormond-Parker, Lyndon, Marcia Langton, Sharon Huebner, Jasper Coleman, Caden Pearson, Robyn Sloggett, Rachel Nordinger, Kristen Smith, and 
Ken Clarke.When Magnets Collide: Digital Preservation and Access of At-Risk Audiovisual Archives in a Remote Aboriginal Community. Melbourne:

Meelbourn Networked Society Institute, The University of Melbourne, 2015.

Payne, Carol and Jeffrey Thomas, "Aboriginal Interventions into the Photographic Archives." Visual Resources: An International Journal of Documentation, XVIII, no. 2 (June 2002): 109-125.

Payne, Carol. "Lessons with Leah: re-reading the photographic archive of nation in the National Film Board of Canada's Still Photography Division." Visual studies 21, no. 1 (2006): 4-22.

Sandweiss, Martha A. Print the Legend: Photography and the American West. New Haven and London: Yale University Press, 2002.

Sassoon, Joanna. "Photographic Materiality in the Age of Digital Reproduction." In Photographs Objects Histories: On the Materiality of Images, eds. Elizabeth Edwards and Janice Hart, 186- 202. London and New York: Routledge, 2004.

Schwartz, Joan M. “Coming to Terms with Photographs," Archivaria 54 (2002): 142 - 171. Sekula, Allan. Mining Photographs and Other Pictures, 1948 1968. Halifax: Press of the Nova Scotia College of Art and Design and the University College of Cape Breton Press, 1983.

Smith, David A. "From Nunavut to Micronesia: Feedback and Description, Visual Repatriation and Online Photographs of Indigenous Peoples." The Canadian Journal of Library and Information Practice and Research 3, no. 1 (2008): $1-19$. 